$1-1986$

\title{
Decentralization, Redistribution and Community Development: A Reassessment of the Small Cities CDBG Program
}

Eric B. Herzik

Texas A \& M University

John P. Pelissero

Loyola University Chicago, jpeliss@luc.edu

Follow this and additional works at: https://ecommons.luc.edu/politicalscience_facpubs

Part of the Political Science Commons

\section{Recommended Citation}

Herzik, Eric B. and John P. Pelissero, "Decentralization, Redistribution and Community Development: A Reassessment of the Small Cities CDBG Program," Public Administration Review 46 (January/February 1986): 31-36.

This Article is brought to you for free and open access by the Faculty Publications and Other Works by Department at Loyola eCommons. It has been accepted for inclusion in Political Science: Faculty Publications and Other Works by an authorized administrator of Loyola eCommons. For more information, please contact ecommons@luc.edu. (c) (i) $\Theta$

This work is licensed under a Creative Commons Attribution-Noncommercial-No Derivative Works 3.0 License. 


\title{
Decentralization, Redistribution and Community Development: \\ A Reassessment of the Small Cities CDBG Program
}

\author{
Eric B. Herzik, Texas A\&M University \\ John P. Pelissero, Loyola University of Chicago
}

The proper balance between federal initiative and state control in policy administration has always been a volatile issue in American politics. The Reagan administration is actively pursuing a program that it hopes will reduce the size and scope of the national government, decentralize program and policy administration, and revitalize state government.' An initial step toward decentralization came with the Omnibus Budget Reconciliation Act of 1981 (OBRA81), which consolidated more than 50 categorical grants into nine block grants. Under the block grant approach, most of these grant programs will now be under administrative control of state governments rather than federal agencies.

While the administrative direction of the Reagan approach is clear, the policy implications have yet to be systematically analyzed. This paper is an analysis of changes in one particular block grant altered by OBRA81, the small cities portion of the Community Development Block Grant (CDBG) program. Following Morgan and England's recent article in $P A R,{ }^{2}$ we are primarily concerned with the question of redistribution. Particular attention is focused on the proposition that decentralization weakens the redistributive character of policy allocation. The specific empirical question addressed is: have shifts in funding priorities developed with the change from Department of Housing and Urban Development (HUD) to state administration of the small cities program? We also analyze the use of single purpose and multipurpose grants by both HUD and the states. Finally, changes are assessed within the context of CDBG as a developing state program. The data consist of cross-sectional samples of states administering the program for one or two years.

\section{CDBG: Creation and Development}

Several recent studies have analyzed the small cities CDBG program under state assumption. ${ }^{3}$ While instructive, these studies have generally suffered from two common shortcomings. First, they are almost exclusively studies of a single state or small group of states. Second, the analysis often fails to consider the broader context of the CDBG program. Specifically, federal
Recent studies of state assumption of the $C D B G$ Small Cities program have been limited by two factors. First, they have been single-state case studies or confined to a small number of states. Second, they have adopted a narrow context for examining the likely impacts of community development following state assumption. This paper attempts to expand policy information based upon earlier work by studying a larger cross-section of states and considering the issues of redistribution and decentralization from a broader context. We find some significant policy changes from previous HUD program management but suggest that such may be due to the CDBG economic development amendment and an increase in multipurpose projects in the states. Unlike Morgan and England's (1984) recent article in PAR, we suggest that decentralization may not necessarily lead to decreasing redistributive community development policies in the states. Rather, redistribution may be incorporated within the enlarging proportion of multipurpose projects.

funding priorities are often compared to state priorities without considering legal and structural changes in the CDBG program. Our cross-sectional data, including a majority of states administering the CDBG program, allows us to address the first flaw. A short discussion of the CDBG program, particularly changes wrought by amendments in 1978 and 1981, addresses the second.

When the CDBG program was created in 1974 , the overarching goal of the new block grant was "the development of viable urban communities, ... principally for persons of low and moderate income." 4 Initially, there were seven specific objectives to which local communities could apply funds: elimination of slums and blight, elimination of detrimental conditions, conservation and expansion of housing stock, more rational land utilization, improvement of community services, reduction of income group isolation, and historic preservation. ${ }^{5}$ From the outset, the primary uses of CDBG funds were for neighborhood development, housing rehabilitation for low and moderate income families, and infra- 
structure improvements. Secondary uses of funds favored water and sewer projects, street and drainage improvements, and assistance to community organizations that aid low and moderate income residents. ${ }^{6}$

However, two amendments have significantly broadened the scope of activities "eligible for funding", through CDBG and its small cities program. In 1978, the Carter administration allowed communities to grant funds to public or private nonprofit entities for the alleviation of physical and economic distress. ${ }^{7}$ This was followed by a Reagan administration initiated amendment that allowed for even more aggressive economic development programs through the "provision of assistance to private, for-profit entities.",

Both the Carter and Reagan amendments shifted CDBG away from a strictly housing and services orientation. The bias in the program is still toward housing and public works, but the changes in CDBG permitting economic development projects should be incorporated into any analysis of states' small cities CDBG funding. Empirically, funding in traditional $\mathrm{CDBG}$ project categories will necessarily decrease as economic development projects come "up to speed" from their initiating amendments of 1978 and 1981. However, past analyses have often failed to consider the impact these changes may have on $C D B G$ spending priorities.

An analysis of CDBG's development also suggests that targeting of benefits for low-income groups has varied somewhat through three administrations. The Carter administration emphasized a more direct redistributive effort in the allocation process, an emphasis not as apparent under either Ford or Reagan. The uncertain standard of redistributive benefit is apparent in the CDBG legislation, which stresses selection of projects that benefit low-income groups while establishing no specific target figures. This further complicates any subsequent analysis of state redistributive efforts, as we highlight below.

\section{CDBG Under State Administration}

Following OBRA81, states could assume complete administrative responsibility from HUD for the small cities program. In assuming control of the program a state must agree to two basic conditions: (1) a continuation of previously approved multi-year projects, and (2) adherence to the national objectives of the CDBG Act. In the first year of state assumption, 36 states administered their own Small Cities programs. Since then the number of states opting for control has risen to 47 .

Initial analysis of the effects of state assumption have produced varied results. The GAO studied seven states in 1982-83 to see what changes might result from state approved projects. In six of the states, approved projects would result in a reduction in direct benefits to low and moderate income groups compared to HUD administration. The primary shift observed with state assumption was a marked decline in housing funds and a concomitant increase in public works and economic development monies. Although these were planned allocations of CDBG funds, the report cautioned that a shift from housing related activities to public facilities or economic development may not indicate a decline in targeting to needier groups. Rather, the areal benefits of improved public facilities and economic development activities may also benefit needier groups. ${ }^{\circ}$ A recent ACIR report echoes these findings. The commission found more monies going to economic development under state administration with a proportional decline in housing rehabilitation activities. In addition, unlike HUD, these states appear to spread the monies across more communities. ${ }^{10}$

The recent annual CDBG report by HUD adds further confirmation to the earlier reports. Reviewing the project activities funded by the states in 1982 and 1983 reveals that public works showed gains in both the number of grants and funding levels and a similar pattern was evolving in the economic development area (but its funding proportion actually dropped in 1983). The number of housing grants has declined from HUD days, too, with proportional funding shares at less than half of the former HUD-administered level." Similarly, in a case study of Oklahoma following state assumption, Morgan and England found that state officials awarded monies to local areas primarily for public works. The state also allocated CDBG monies to a larger number of cities on a somewhat less competitive basis than employed by HUD. ${ }^{2}$

These studies point to programmatic changes in the small cities program during state assumption. Of primary interest is whether these changes have led to a restructuring of national objectives. In particular, has there been a shift from the national redistributive goals of small cities CDBG to state determined ones? Have similar types of projects been funded under state administration? Are more cities being funded by the state? Is targeting to needier areas an active process in the states? Analysis of these questions allows broader questions of change in American federalism to be addressed. Specifically, if the nature of state changes in this program are not consonant with federal goals, then the movement toward increased decentralization of federal programs may be undesirable. This would also support the proposition that decentralization impedes efforts of resource redistribution. Conversely, state administrative changes that effectively incorporate congressionally determined national interests would cast doubt on the proposition and add impetus to an expanded state role in policy administration. We now turn to an examination of these questions embodied in the shift from HUD to state administration in the small cities CDBG program.

\section{Data}

The data for this study are drawn from annual reports which each state is obligated to file concerning projected and actual use of CDBG funds and were obtained from the Council of State Community Affairs Agencies (COSCAA). Two samples of states have been con- 
structed from the state data. The first group includes 26 states' small cities awards during each state's first administrative year (either 1982 or 1983). The second sample contains 12 states that have two years' (both 1982 and 1983) experience as program managers. The two samples allow us to assess the states' initial year with the program and to search for differences when compared to the two year composite for states with a slightly longer history with the program. An additional sample is based upon the 51 states (including Puerto Rico) receiving funds under the program in 1981. For each state, the actual small cities CDBG expenditures were collected for public works (includes public facilities and services), housing, economic development, and multipurpose projects. These funding totals do not include any "hold-harmless" projects continued from HUD multi-year commitments.

\section{Analysis}

A first test in assessing change in small cities CDBG is to determine whether spending priorities have shifted with state assumption. As Table 1 indicates, some significant changes have occurred in the types of projects funded by the states. In 1981 under HUD, housing received one-third of $C D B G$ dollars. The experience with state assumption shows that housing activities were cut in half. Conversely, economic development projects have enjoyed major gains. Any shift in funding toward economic development must be analyzed within the broader context of the CDBG program. As noted above, economic development activities were first eligible for funding in 1978 and then expanded by the Reagan administration in 1981. Thus, a shift in proportional allocations should be expected as this new project category comes on board. But how much of a funding shift is reasonable? While no single figure or expenditure total is absolute, HUD planners projected that 16 percent of available funds would be targeted to economic development projects by 1982.13 Thus, the state increase is slightly higher than expected for the sample states' first year and slightly lower over two years.

Public works and multipurpose grants show little change from 1981 during the states' first year. But states with two years' experience have actually decreased (on average) the proportion of funding to public works and given multipurpose projects the largest share of the CDBG pie. These findings are not consistent with the trends that were reviewed above from the research by the GAO and HUD. Since the declining share of CDBG funds for public works is also not similar to Morgan and England's findings in Oklahoma, while the housing and economic development trends are relatively consistent with their work, we need to address the issue further.

Based upon these aggregate figures a circumstantial case might be forwarded, suggesting that states are displacing the redistributive aspects of the small cities program. This would be consistent with the seven-state $\mathrm{GAO}$ analysis performed in 1982. In essence, states may be seen as eschewing the direct link of benefits that accrue to low and moderate income groups through improved housing for more areal benefits contained in economic development projects. Moreover, economic and employment benefits for lower income individuals are often negligible in such projects since these benefits more closely represent collective goods. ${ }^{14}$

While this is a valid concern and would demonstrate a frustration of national objectives, such a conclusion on state intent is premature. While funding for single purpose housing rehabilitation projects has declined, the overall dollars for this activity may be relatively constant. This would be true if housing rehabilitation projects are a major component of state multipurpose project awards. Table 2 shows an analysis of the state multipurpose grants and indicates that the largest portion of funds distributed by states during their first year

\section{TABLE 1 \\ Distribution of Small Cities CDBG Funds by Project Activity During HUD and State Administration}

\begin{tabular}{|c|c|c|c|}
\hline \multirow[b]{2}{*}{ Project Activity } & \multicolumn{3}{|c|}{ Percent of Grant Expenditures by: } \\
\hline & HUD $(1981)^{\mathrm{a}}$ & States $(1 \text { year })^{b}$ & States $(2 \text { years })^{\circ}$ \\
\hline Housing & $33 \%$ & $17 \% *$ & $16 \%$ \\
\hline Public Works/Facilities & 38 & 37 & 29 \\
\hline Economic Development & 4 & $18^{*}$ & 14 \\
\hline Multipurpose and Others & 25 & 28 & 41 \\
\hline Total & $100 \%$ & $100 \%$ & $100 \%$ \\
\hline$(\mathrm{N})$ & $(51)$ & $\cdot(26)$ & $(12)$ \\
\hline
\end{tabular}


TABLE 2

Project Activities Included in State Administered Multipurpose Grants

\begin{tabular}{lcc}
\hline & \multicolumn{2}{c}{ Percent of Multipurpose Expenditures } \\
\cline { 2 - 3 } Project Activity & Year 1 & Years 1 and $2^{\mathrm{h}}$ \\
\hline Housing/Public Works & $39 \%$ & $22 \%$ \\
Housing/Economic Development & 10 & 11 \\
Housing/Public Works/Economic Development & 6 & 8 \\
Housing and Related Activities & 3 & 5 \\
Public Works/Economic Development & 1 & 6 \\
Public Works and Facilities & 0 & 1 \\
Unspecified & 41 & 47 \\
Toral & $100 \%$ & $100 \%$ \\
(N) & $(26)$ & $(12)$ \\
\hline
\end{tabular}

${ }^{2}$ These data are derived from individual state reports filed with COSCAA and include the first year of state administration, either 1982 or 1983.

'These data include two years' experience with state administration by 12 states, both 1982 and 1983 .

incorporated a housing component. While sightly less than 50 percent of multipurpose grants over two years in the second sample incorporated housing, it is clearly a predominant component of the multiple activities. (Both sets of housing figures in Table 2 are undoubtedly larger because several states did not provide a description of each project and had to be placed in the "unspecified" category.) Thus, the observed decline in housing dollars may be more a function of changes in grant administration than policy redirection, particularly in states approving more multipurpose grants for their communities.

More significant change may be occurring in administrative procedures rather than policy direction. As the figures in Table 1 demonstrate, states are increasing the use of multipurpose grants. This finding is certainly at odds with some previous single state studies in which formal multipurpose programs were terminated. Possibly, this difference reflects the use of multi-activity projects that we observed in the data, as in states like California that no longer have a separate program called multipurpose projects. ${ }^{15}$ Our sample states also appear to be awarding more grants than under HUD administration. While state-by-state grant awards under HUD are unavailable for our sample states, an indication of this change might be the average small cities CDBG grants awarded by the states. In 1981, grants awarded by HUD averaged $\$ 493,000 .^{10}$ The average state administered awards are substantially smaller: $\$ 280,619$ for the sample states in their first year, and $\$ 337,356$ for 12 states over two years. As the total funding level of the CDBG program has either remained constant or in many states has been expanded with state funds, this appears to indicate that the states are awarding grants to a larger number of cities, although for smaller dollar amounts. One implication of this trend may be that CDBG benefits are now available to more low and moderate income groups in more communities across a state than was the case under HUD.

\section{Discussion}

Previous research has posited that redistributive programs may be significantly and unfavorably altered as the decision-making arena is narrowed, with national interests being supplanted by more parochial concerns. ${ }^{17}$ If states substitute their own priorities for national goals, a consistent bias discriminating against intended beneficiaries may develop. This would further strengthen existing interests and inequalities, a situation which on its face would be undesirable.

Recently, Morgan and England have added empirical support to the belief that states lack the political will necessary to pursue redistributive policies. Analyzing the small cities CDBG program in Oklahoma, they conclude: "In small cities, especially in the Sunbelt, it seems likely that maximum local autonomy under a statecontrolled CDBG program may not result in assistance to those most in need." 18

The results of our cross-sectional analysis of states participating in the small cities program is at odds with the theoretical argument concerning the effects of policy decentralization and the findings of Morgan and England. Policy shif ts that have occurred may be largely explained by two factors unrelated to decentralization and not examined in the Morgan and England research. First, programmatic changes in CDBG approved by Congress prior to state assumption have invited changes in funding allocations. This specifically concerns the decreasing share of funds for housing and other programs that followed the inclusion of economic development as an eligible project activity. Given the opportunity to conduct an economic development project, many communities opted to do so; hence, the overall averages would have to reflect an increase here with a decline in most other preexisting funding categories.

In addition to this programmatic shift, the type of grant utilized by states further mediates the observed 
TABLE 3

Simple Correlation Coefficients Between State Use of Multipurpose Grants and State Approved Housing Expenditures for Small Cities

\begin{tabular}{|c|c|c|}
\hline \multirow{2}{*}{$\begin{array}{l}\text { Proportion of Community } \\
\text { Development Grants for } \\
\text { Multipurpose Projects in: }\end{array}$} & \multicolumn{2}{|c|}{ Total Expenditures on: } \\
\hline & $\begin{array}{l}\text { Single Purpose } \\
\text { Housing Projects }\end{array}$ & $\begin{array}{c}\text { All } \\
\text { Housing Projects }\end{array}$ \\
\hline & $\mathrm{r}$ & r \\
\hline Year $1(n=26)$ & -.18 & $.37^{*}$ \\
\hline Years 1 and $2(n=12)$ & -.22 & $.43^{* *}$ \\
\hline
\end{tabular}

shift in emphasis away from redistributive housing and related activities. Here the focus is on the use of multipurpose grants. The sample states show more reliance on this type of grant than was true about all states in 1981. The mediating effect results from the fact that about half of these states' multipurpose grants incorporated a housing activity. If housing is still a major emphasis in states but is being masked by its incorporation into multipurpose projects, then states may not be shifting away from redistribution. Table 3 presents a test of this interpretation. The table first shows the correlation between the proportion of multipurpose grants awarded by each state and the total dollars allocated to housing through single purpose grants. We expect a negative relationship since as multipurpose grants increase we assume a related decrease in single purpose housing awards. As expected, there is a small, negative correlation for both of our samples (though statistically insignificant). While larger proportions of multipurpose awards are related to less money for housing in our samples, this does not mean that they have necessarily shifted money away from housing activities. As we note above, the majority of multipurpose grants incorporate housing activities. We then correlated the proportion of multipurpose grants awarded by each state with their total dollars allocated to housing through both single purpose and multipurpose grants. In both cases, this correlation is positive, moderately strong, and close to acceptable levels of significance. Stated substantively, states with a higher proportion of multipurpose grants also have higher dollar allocations to housing activities as a whole. The difference between HUD and state administration, therefore, may not be one of policy redirection but rather of allocational distinctions across states. This further highlights a difference between our results and those of Morgan and England. Our sample states generally show increasing use of multipurpose grants while Oklahoma eliminated this type of award in its program.

\section{Conclusion}

The small cities CDBG program is one of the earliest articulations of the broader Reagan policy of decentralizing policy planning and administration to state governments. As such, this state-centered federalism program provides a key test as to the potential consequences of state assumption of what were previously federal responsibilities. Based on our analysis, concern that the redistributive focus of formerly federal programs will diminish with state assumption may be overstated. By considering an expanded sample of states and the broader context of the small cities program, we find that policy goals have remained relatively constant in this initial translation of federal policy by the states. Changes have occurred, but for the most part these concern different administrative procedures pursued by the states rather than evidence of policy redirection. Indeed, the case can be made that these different administrative procedures are leading to greater involvement by local communities. There may also be greater dispersion of resources as more grants are awarded to a larger number of communities under state programs. Additionally, the increased use of multipurpose grants may be evidence of a more integrated problem-solving orientation in community development policies formulated by the states. This is not to suggest that inequities have not developed in particular states and communities. Considerable variation may exist state-to-state or, more likely, community-to-community. However, the data in this case do not support the conclusion that decentralization will necessarily lead to decreasing levels of redistributive benefits.
We would like to thank Robert England of Oklahoma State University and fon Bond and Hatres Tuker of Terah A\&M Unisersity for their helpful comments on earlier versions of this manuscript. We owe special thanks to James S. Granato who ably assisted us with data collection and analysis. Any errors in this manuscript are, of course, entirely our responsibility. 
1. For a discussion of Reagan administration initiatives, see Deil S. Wright, "New Federalism: Recent Varieties of an Older Species," American Review of Public Administration, vol. 16 (Spring 1982), pp. 56-73; and Richard S. Williamson, "Community Development Block Grants," The Urban Lawyer, vol. 14 (Spring 1982), pp. 283-301.

2. David R. Morgan and Robert E. England, "The Small Cities Community Development Block Grant Program: An Assessment of Programmatic Change Under State Control," Public Administration Review, vol. 44 (November/December 1984), pp. $477-482$.

3. Ibid. See also Edward T. Jennings, "Implementation of the Small Cities Community Development Block Grant Program in Missouri: Impact and Reaction," paper presented at the Annual Meeting of the Midwest Political Science Association, Chicago, Illinois, April 20-23. 1984; Advisory Commission on Intergovernmental Relations, "Block Grant Implementation: A Preliminary Review of the Second Year's Experience," Information Bulletin, no. 84-1 (January 1984), pp. 1-23; and U.S. General Accounting Office, States Are Making Good Progress in Implementing the Small Cities Community Development Block Grant Program (Washington, D.C., September 1983).

4. U.S. Congress, 1974 Housing and Community Development Act, Public Law 93-183 (August 22, 1974).

5. U.S. Department of Housing and Urban Development, Community Development Block Grant Program: First Annual Report (Washington, D.C., 1975), pp. 28-29.

6. John W. Ellwood, Reductions in U.S. Domestic Spending (New Brunswick, N.J.: Transaction Books, 1982), p. 167.

7. U.S. Department of Housing and Urban Development, Fifth Annual Community Development Block Grant Report (Washington, D.C., 1980).
8. U.S. Congress, 1981 Amendments to the Housing and Community Development Act, Public Law 97-35 (1981).

9. U.S. General Accounting Office, 1983, pp. 15-22.

10. Advisory Commission on Intergovernmental Relations, 1984.

11. U.S. Department of Housing and Urban Development, Consolidated Annual Report to Congress on Community Development Programs (Washington, D.C., 1984), p. 59.

12. Morgan and England, 1984.

13. This estimate is for entitlement cities (cities with populations of 50,000 or more and urban counties of 200,000 or more population). No separate calculation was made for the small cities group. However, as the distribution of funds in both entitlement and small cities has been fairly comparable, we believe the 16 percent figure is a valid estimate.

14. For an example, see Jeffrey Pressman and Aaron Wildavsky, Implementation (Berkeley: University of California Press, 1973).

15. Morgan and England, 1984; and Ted P. Robinson, "The State Assumption of the Small Cities Community Development Block Grant Program: The Case of California," paper presented at the Annual Meeting of the Southwestern Political Science Association, Fort Worth, Texas, March 21-24, 1984

16. U.S. Department of Housing and Urban Development, Consolidated Annual Report to Congress on Community Development Programs (Washington, D.C., 1982), p. 46.

17. E. E. Schattschneider, The Semi-Sovereign People (New York: Holt, Rinehart and Winston, 1960); William H. Riker, Federalism: Origin, Operation, Significance (Boston: Little, Brown \& Co., 1964).

18. Morgan and England, 1984, p. 481. 